\title{
Konsekuensi Pilihan Bentuk Badan Hukum Perasuransian Di Indonesia
}

\author{
Nurjihad \\ Fakultas Hukum Universitas Islam Indonesia Yogyakarta Indonesia \\ Jln. Tamansiswa No. 158, Yogyakarta Indonesia \\ nurjihad@uii.ac.id
}

Received: 18 Juni 2021; Accepted: 12 November 2021; Published: 31 Januari 2022

DOI: 10.20885/iustum.vol29.iss1.art6

\begin{abstract}
The focus of this research is to offer an option for the ideal insurance business legal entity form. This study aims at two things. First, to examine the legal consequences on the choices of various legal entities to administer insurance. Second, to analyze the ideal form of legal entity for insurance business. This is a normative legal research with regulatory and conceptual approaches. The presentation of the analysis is carried out in a qualitative descriptive manner. The results of the study conclude that: first, the legal consequences of the insurance provider are the characteristics inherent in the legal entity form of the provider. Second, although a Limited Liability Company (PT) according to the legal form is the most appropriate legal entity in administering insurance, Cooperation and Mutual have advantages in unifying the ownership and consumer functions. Their goal is to focus more on togetherness and ensuring member satisfaction and not just making a profit. This uniqueness can have a positive impact on reducing potential conflicts of interest between consumers and company owners which are common in PT. The form of Cooperative and Mutual is more in line with the mandate of Article 33 paragraph (1) of the 1945 Constitution of the Republic of Indonesia.
\end{abstract}

Key Words: Insurance legal entity; limited company; mutual; cooperation

\section{Abstrak}

Fokus penelitian ini menawarkan pilihan bentuk badan hukum usaha perasuransian yang tepat (ideal). Penelitian ini bertujuan untuk memperoleh dua hal. Pertama, mengkaji konsekuensi hukum pilihan berbagai badan hukum penyelenggaran asuransi. Kedua, menganalisis bentuk badan hukum yang ideal usaha perasuransian. Jenis penelitian merupakan jenis penelitian normatif dengan pendekatan perundang-udangan dan konseptual. Penyajian analisis dilakukan secara deskriptif kualitatif. Hasil penelitian menyimpulkan bahwa: pertama, konsekuensi hukum penyelenggara perasuransian adalah bergantung pada karakteristik yang melekat pada bentuk badan hukum penyelenggara tersebut. Kedua, meskipun bentuk Perseroan Terbatas (PT) menurut pandangan pembentuk Undang-Undang merupakan badan hukum yang paling tepat dalam menyelenggarakan perasuransian, namun Koperasi dan Mutual memiliki keunggulan dalam penyatuan fungsi kepemilikan dan fungsi konsumen. Tujuan keduanya lebih fokus pada kebersamaan serta memastikan kepuasan anggota dan bukan sekedar menghasilkan profit. Keunikan ini bisa berdampak positif mengurangi potensi konflik kepentingan antara konsumen dengan pemilik perusahaan yang umum terjadi pada PT. Bentuk Koperasi dan Mutual lebih berkesesuaian dengan amanat Pasal 33 ayat (1) Undang-Undang Dasar Negara Republik Indonesia Tahun 1945.

Kata-kata Kunci : Badan hukum perasuransian; perseroan terbatas; mutual; koperasi 


\section{Pendahuluan}

Usaha perasuransian dalam skala nasional maupun global mengalami perkembangan yang pesat ditandai dengan meningkatnya volume usaha dan bertambahnya pemanfaatan layanan jasa perasuransian oleh masyarakat secara umum. Kebutuhan masyarakat akan pengelolaan risiko dalam kehidupan pribadi maupun kegiatan usaha yang semakin berkembang, memunculkan layanan jasa perasuransian yang semakin bervariasi. Perkembangan usaha perasuransian tersebut beriringan dengan perkembangan berbagai usaha dibidang perekonomian lainnya, khususnya di bidang jasa keuangan. Fenomena percepatan inovasi beragam produk/jasa keuangan, termasuk di bidang perasuransian, di pengaruhi faktor perubahan dan perkembangan teknologi dan sistem informasi yang sangat pesat. Regulasi asuransi baik konvensional maupun syariah terdapat dalam Undang-Undang (UU) Nomor 40 Tahun 2014 tentang Perasuransian, yang menggantikan UU Nomor 2 Tahun 1992 tentang Usaha Perasuransian. UU ini, sebagaimana tersebut dalam penjelasan umumnya, terbit sebagai upaya untuk menciptakan industri perasuransian yang lebih sehat, dapat diandalkan, amanah, dan kompetitif yang diwujudkan antara lain dalam bentuk:

a. penetapan landasan hukum bagi penyelenggaraan usaha asuransi syariah;

b. penetapan status badan hukum bagi Perusahaan Asuransi berbentuk usaha bersama yang telah ada pada saat UU ini diundangkan;

c. penyempurnaan pengaturan mengenai kepemilikan perusahaan perasuransian yang mendukung kepentingan nasional;

d. pemberian amanat lebih besar kepada perusahaan asuransi syariah untuk mengelola kerja sama dengan pihak lain dalam rangka pemasaran layanan jasa asuransi dan asuransi syariah, termasuk kerja sama keagenan; dan

e. penyempurnaan ketentuan mengenai kewajiban untuk menjaga tata kelola perusahaan yang baik, kesehatan keuangan, dan perilaku usaha yang sehat.

Setidaknya terdapat dua hal yang menarik perhatian berkaitan dengan lahirnya UU Nomor 40 Tahun 2014. Pertama, UU ini merespon tumbuh kembangnya ekonomi syariah berikut lembaga-lembaga ekonomi syariah termasuk asuransi syariah; kedua, formulasi pengaturan mengenai bentuk badan hukum asuransi. Adapun mengenai bentuk badan hukum asuransi mengalami perubahan pengaturan dari regulasi sebelumnya. Pasal 7 ayat (1) UU Nomor 2 Tahun 1992 tentang Usaha Perasuransian 
menegaskan bahwa usaha perasuransian hanya dapat dilakukan oleh badan hukum yang berbentuk perusahaan perseroan (Persero), koperasi dan usaha bersama (mutual). Dalam ayat (3) pasal tersebut menyatakan usaha perasuransian mutual diatur lebih lanjut dengan UU.

Terhadap ketentuan tersebut beberapa orang pemegang polis Asuransi Jiwa Bersama (AJB) Bumiputera 1912, setelah 21 tahun tidak ada kepastian hukum karena belum juga terbit UU yang mengatur tentang mutual sebagaimana perintah Pasal 7 ayat (3) di atas, mengajukan uji materi ke Mahkamah Konstitusi. Menurut para pemegang polis selaku pemohon, hal itu tidak sejalan dengan Pasal 28D ayat (1) UUD 1945 dan menimbulkan perlakuan yang tidak sama dihadapan hukum (non equality before the law) sehingga bertentangan dengan Pasal 27 ayat (1) UUD 1945.

Pemegang polis secara konstitusional dirugikan, meliputi: ${ }^{1}$ (1) hilangnya hak warga negara untuk mendapatkan pengaturan badan hukum usaha bersama (mutual) seperti halnya perseroan terbatas maupun koperasi, yang keduanya dilindungi oleh UU Nomor 40 Tahun 2007 tentang Perseroan Terbatas dan UU Nomor 17 Tahun 2012 tentang Perkoperasian; (2) tidak adanya perlindungan yang memadai atas hak-hak anggota/pemegang polis dalam usaha perasuransian yang berbentuk usaha bersama (mutual), berbeda hal nya dengan yang berbentuk persero atau koperasi sehingga bertentangan dengan asas keadilan; (3) potensi kerugian AJB Bumiputera 1912 (sebagai usaha perasuransian yang ber badan hukum Mutual) sebab fasilitas dari negara/pemerintah/badan usaha lain gagal diperoleh karena tidak mendapatkan kesempatan untuk bisa ikut dalam tender pengadaan jasa/barang (tidak memiliki persyaratan tender yaitu: akta pendirian perusahaan dan surat pengesahan sebagai badan hukum dari Kementerian Hukum dan HAM; (4) peserta/pemegang polis selaku pemilik badan usaha tersebut tidak memiliki legalitas yang kuat untuk mendapatkan bagian keuntungan/laba seperti halnya hak deviden bagi pemilik/pemegang saham perusahaan atau sisa hasil usaha (SHU) jikalau badan usaha koperasi.

Sebelum menjatuhkan amar putusan di atas, dalam pertimbangan hukumnya, mahkamah menegaskan bahwa pembangunan ekonomi memerlukan dukungan investasi dalam jumlah yang memadai dan pelaksanaannya harus

\footnotetext{
${ }^{1}$ Lihat Putusan Mahkamah Konstitusi Republik Indonesia Nomor 32/PUU-XI/2013, hlm. 10-14.
} 
berdasarkan kemampuan sendiri, oleh karena itu diperlukan usaha yang sungguh-sungguh untuk mengerahkan dana investasi, khususnya yang bersumber dari tabungan masyarakat. Investasi dapat dihimpun melalui, antara lain, lembaga perbankan dan asuransi. Usaha perasuransian sebagai salah satu usaha jasa keuangan menjadi penting peranannya, karena dari kegiatan usaha ini diharapkan dapat semakin meningkatkan pengerahan dana masyarakat untuk pembiayaan pembangunan. Oleh karenanya agar semua badan hukum asuransi (Persero, Koperasi, maupun Mutual) memperoleh perlindungan dan kepastian hukum dalam menjalankan usahanya, maka setiap bentuk usaha perasuransian memerlukan pengaturan dalam bentuk UU. ${ }^{2}$

Respon pemerintah atas putusan MK tersebut bukannya menerbitkan UU tentang usaha perasuransian yang berbentuk usaha bersama (mutual), melainkan mengganti UU Nomor 2 Tahun 1992 dengan UU Nomor 40 Tahun 2014 tentang Perasuransian. Dalam UU tersebut bahkan menutup bentuk badan hukum penyelenggara usaha perasuransian dari sebelumnya bisa berbentuk perusahaan perseroan (persero), koperasi dan usaha bersama (mutual), menjadi perseroan terbatas dan koperasi saja. Adapun bentuk badan usaha bersama yang diakui hanya yang telah ada pada saat pengundangan UU Nomor 40 Tahun 2014.

UU Perasuransian di atas (khususnya Pasal 6 ayat (3)) ${ }^{3}$ di penghujung April 2020 dipersoalkan dan digugat ke Mahkamah Konstitusi dikarenakan frasa yang berbunyi "diatur dalam Peraturan Pemerintah" tidak konstitusional. Frasa tersebut mengubah norma yang diatur dan dipertimbangkan dalam Putusan Mahkamah Konstitusi Nomor 32/PUU-XI/2013.4 Dalam putusannya (Nomor 32/PUU-XVII/2020), Mahkamah menyatakan pada pokoknya tindakan pembentuk UU (Pemerintah dan DPR) tidak melaksanakan putusan Mahkamah Konstitusi Nomor 32/PUU/XI/2013 adalah bentuk ketidaktaatan terhadap

${ }^{2}$ Ibid., hlm. 89-90.

${ }^{3}$ Pasal 6 ayat (3) UU Nomor 40 Tahun 2014 berbunyi: Ketentuan lebih lanjut mengenai badan hukum usaha bersama sebagaimana dimaksud pada yat (2) diatur dalam Peraturan Pemerintah.

${ }^{4}$ Putusan Mahkamah Konstitusi Nomor 32/PUU-XI/2013 menyatakan: Frasa “...diatur lebih lanjut dengan Undang-Undang” dalam Pasal 7 ayat (3) Undang-Undang Nomor 2 Tahun 1992 tentang Usaha Perasuransian (Lembaran Negara Republik Indonesia Tahun 1992 Nomor 13, Tambahan Lembaran Negara Republik Indonesia Nomor 3467), bertentangan dengan Undang-Undang Dasar Negara Republik Indonesia Tahun 1945, sepanjang tidak dimaknai “... 'diatur lebih lanjut dengan Undang-Undang' dilakukan paling lambat dua tabun enam bulan setelah putusan Mabkamah ini diucapkan" 
hukum. ${ }^{5}$ Dalam amar putusan nya bertanggal 14 Januari 2021, Mahkamah memutuskan bahwa frasa "...diatur dalam Peraturan Pemerintah" bertentangan dengan UUD 1945 dan tidak mempunyai kekuatan hukum mengikat, dan diubah menjadi "Ketentuan lebih lanjut mengenai badan hukum usaha bersama sebagaimana dimaksud pada ayat (2) diatur dengan UU".6 Oleh karenanya, kepastian mengenai legalitas bentuk badan hukum perasuransian sangat penting bagi pelaku usaha maupun pemegang polis berkaitan dengan tumbuh kembangnya bisnis asuransi berikut hak dan kewajiban pemegang polis.

\section{Rumusan Masalah}

Studi ini menitikberatkan pada dua rumusan masalah. Pertama, bagaimana konsekuensi pilihan berbagai badan hukum penyelenggaran asuransi? Kedua, bagaimana bentuk badan hukum yang ideal usaha perasuransian?

\section{Tujuan Penelitian}

Berdasarkan identifikasi masalah di atas, penelitian ini bertujuan untuk memperoleh dua hal. Pertama, mengkaji konsekuensi pilihan berbagai badan hukum penyelenggaran asuransi. Kedua, menawarkan bentuk badan hukum yang ideal terhadap badan hukum usaha asuransi.

\section{Metode Penelitian}

Untuk menjawab persoalan tersebut, metode yang digunakan adalah penelitian hukum normatif ${ }^{7}$ dengan menggunakan pendekatan perundangundangan (statue approach) dan pendekatan konseptual (conceptual approach). ${ }^{8}$ Data yang digunakan ialah data sekunder. Analisis dilakukan secara deskriptif kualitatif yaitu data yang diperoleh diklasifikasikan sesuai permasalahan penelitian kemudian disusun secara sistematis sehingga diperoleh gambaran yang jelas dan menghasilkan kesimpulan yang dapat menjawab pemasalahan penelitian ini.

\footnotetext{
5 Putusan Mahkamah Konstitusi Nomor 32/PUU-XVII/2020, hlm. 129.

${ }^{6}$ Amar Putusan Mahkamah Konstitusi Nomor 32/PUU-XVII/2020.

${ }^{7}$ Lili Rasjidi dan Liza Sonia Rasjidi, Pengantar Metode Penelitian dan Penulisan Karya Ilmiah Hukum, FH Unpad, Bandung, 2005, hlm. 10.

8 Peter Mahmud Marzuki, 2016, Penelitian Hukum, Edisi Revisi, Cetakan ke-12, Penerbit Kencana (Prenada Media Group), Jakarta, hlm. 133-136.
} 


\section{Hasil Penelitian dan Pembahasan}

\section{Badan Hukum Penyelenggara Asuransi dan Konsekuensinya Hukumnya}

Asuransi merupakan alternatif mitigasi risiko. Asuransi merupakan suatu produk yang dapat memberikan rasa aman dan menjamin keberlangsungan hidup seseorang, keluarga maupun usahanya. Risiko adalah suatu kondisi yang mengandung kemungkinan terjadinya penyimpangan yang lebih buruk dari hasil yang diharapkan. ${ }^{9}$ Risiko itu terjadi dalam peristiwa tidak tertentu (evenement), akan tetapi pasti terjadi yang waktunya tidak diketahui. ${ }^{10}$

Pada masyarakat modern menyediakan banyak contoh apa yang disebut risiko. Misalnya asuransi ganti kerugian, seseorang badan hukum dan non badan hukum menghadapi kerugian secara ekonomis, disebabkan oleh terbakarnya rumah, kantor dan perusahaan. Demikian halnya asuransi jiwa, manusia yang pasti akan mati tapi tidak tahu kapan waktunya namun (tertanggung) mengasuransikan jiwanya. ${ }^{11}$ Walaupun banyak metode untuk menangani risiko, namun asuransi merupakan metode yang paling banyak dipakai. Asuransi menjanjikan perlindungan kepada pihak tertanggung terhadap risiko yang dihadapi perorangan maupun perusahaan.

Asuransi atau pertanggungan adalah perjanjian antara 2 pihak atau lebih di mana pihak penanggung mengikatkan diri kepada tertanggung dengan menerima premi asuransi untuk memberikan penggantian kepada tertanggung karena kerugian, kerusakan atau kehilangan keuntungan yang diharapkan, atau tanggung jawab hukum kepada pihak ketiga yang mungkin akan diderita tertanggung yang timbul dari suatu peristiwa yang tidak pasti atau untuk memberikan suatu pembayaran yang didasarkan atas meninggal atau hidupnya seseorang yang dipertanggungkan. ${ }^{12}$

\footnotetext{
${ }^{9}$ Emmet J. Vaughter dan Therese Vaughan, Fundamentals of Risk and Insurance, dikutip dari Junaedy Ganie, Hukum Asuransi Indonesia, Ctk. Pertama, 2011, Sinar Grafika, Jakarta, hlm. 40. hlm. 40 .

${ }^{10}$ Scott E. Harrington, Gregory R. Niehaus, Risk Management and Insurance, dikutip dari Junaedy Ganie.,

${ }^{11}$ Emmy Pangaribuan Simanjuntak, Hukum Pertanggungan dan Perkembangannya, Badan Pembinaan Hukum Nasional, Departemen kehakiman, diterbitkan oleh seksi Hukum Dagang Fakultas Universitas Gadjah Mada, Edisi ke 1, Ctk. Pertama, 1980, hlm. 4.

${ }^{12}$ Wirjono Projodikoro, Hukum Asuransi di Indonesia, Cetakan. Kelima, Intermasa, Jakarta, 1991, hlm. 1.
} 
Perusahaan asuransi merupakan suatu lembaga yang sengaja dirancang dan dibentuk sebagai lembaga pengambil alih dan penerima risiko. Perusahaan asuransi pada dasarnya menawarkan jasa proteksi sebagai bentuk produknya kepada masyarakat yang memerlukan, dan selanjutnya diharapkan akan menjadi pelanggannya. Untuk mencapai tujuan tersebut, perusahaan asuransi akan mengajak setiap pihak untuk bergabung ataupun bekerjasama untuk menghadapi kemungkinan-kemungkinan kerugian yang mungkin terjadi yang biasanya tidak disadari dan tidak siap dihadapi.

Asuransi membawa misi ekonomi sekaligus sosial dengan adanya premi yang dibayarkan kepada perusahaan asuransi dengan jaminan adanya pengalihan (transfer) risiko ${ }^{13}$ dari tertanggung kepada penanggung. Asuransi merupakan mekanisme pemindahan risiko di mana seseorang atau badan hukum memindahkan sebagian ketidakpastian sebagai imbalan pembayaran premi. ${ }^{14}$ Definisi risiko disini adalah ketidakpastian terjadi atau tidaknya suatu kerugian. Berdasar manfaat tersebut maka keberadaan lembaga asuransi perlu dipertahankan dan dikembangkan. Namun untuk mengembangkan usaha ini banyak faktor yang perlu diperhatikan seperti antara lain: peraturan perundangundang yang memadai, kesadaran masyarakat, kejujuran para pihak, pelayanan yang baik, tingkat pendapatan masyarakat, pemahaman akan kegunaan asuransi serta pemahaman yang baik terhadap ketentuan perundang-undangan terkait. ${ }^{15}$ Menurut Undang-Undang Nomor 40 Tahun 2014, ada 3 macam bentuk badan hukum penyelenggara usaha perasuransian, yaitu: Perseroan Terbatas (PT), Koperasi dan Usaha Bersama (Mutual).

PT adalah badan hukum ${ }^{16}$ yang memiliki hak-hak untuk melakukan perbuatan seperti orang/manusia, memiliki kekayaan sendiri dan dapat bertindak di hadapan pengadilan. PT didirikan berdasarkan perjanjian (kontrak)

${ }^{13}$ Ketentuan Pasal (1) angka 1 Undang-Undang Nomor 40 Tahun 2014 tentang Perasuransian.

${ }^{14}$ Sentanoe Kertanegara, Asuransi Jiwa dan Pensiun, Agung's, Jakarta, 1991, hlm. 99.

15 Asuransi merupakan salah satu jenis perjanjian khusus yang diatur dalam KUHD. Sebagai perjanjian, maka ketentuan syarat-syarat sah suatu perjanjian dalam KUHPerdata berlaku juga bagi perjanjian asuransi. Karena perjanjian asuransi merupakan perjanjian khusus, maka di samping ketentuan-ketentuan syarat-syarat sah suatu perjanjian, berlaku juga syara-syarat khusus yang diatur dalam Kitab Undang-undang Hukum Dagang.

16 Istilah badan hukum dikenal dengan sebutan "rechtsperson". Pada dasarnya badan hukum adalah suatu badan atau perkumpulan yang dapat memiliki hak-hak dan melakukan perbuatan seperti seorang manusia, serta memiliki kekayaan sendiri, dapat digugat atau menggugat di depan pengadilan. Lihat Subekti, Pokok-Pokok Hukum Perdata, PT. Inter Masa, Jakarta, 1987, hlm. 182. 
secara tertulis yang dilakukan minimal oleh 2 orang atau lebih sebagai pemegang saham tersusun dalam bentuk anggaran dasar dan dimuat dalam akta pendirian yang dibuat di depan notaris. PT bergerak di bidang bisnis dengan tujuan untuk memperoleh keuntungan (laba).

PT merupakan badan hukum persekutuan modal, dengan modal dasar yang seluruhnya terbagi dalam saham. Para Pendiri PT wajib mengambil bagian saham pada saat PT didirikan. Karakteristik mendasar dari PT sebagai corporation adalah sifat badan hukum dan pertanggungjawaban yang terbatas. PT memiliki harta kekayaan tersendiri yang dicatatkan atas namanya sendiri, dan pertanggungjawaban sendiri atas setiap tindakan, perbuatan, termasuk perjanjian yang dibuat. Perseroan dapat mengikat dirinya dalam satu atau lebih perikatan, yang berarti menjadikan perseroan sebagai subyek hukum mandiri. ${ }^{17}$

Tujuan pokok didirikannya PT untuk mencari keuntungan, merupakan konsep yang telah tertuang dalam perumusan Kitab Undang-Undang Hukum Dagang (Wetboek van Koophandel). Menurut Pemerintah Belanda ketika membacakan Memorie van Toelichting (Penjelasan) Rencana Undang-Undang Wetboek van Koophandel di muka parlemen menyebutkan, bahwa perusahaan adalah keseluruhan perbuatan yang dilakukan secara terus menerus, dengan terang-terangan dalam kedudukan tertentu, dan untuk mencari laba bagi dirinya sendiri. Perkembangan pengertian perusahaan dapat dijumpai dalam UU No. 3 Tahun 1982 tentang Wajib Daftar Perusahaan, UU No. 1 Tahun 1995 tentang PT dan UU No. 8 Tahun 1997 tentang Dokumen Perusahaan, sebelum berlaku sekarang ini yaitu UU No. 40 Tahun 2007 tentang PT (menggantikan UU No. 1 Tahun 1995). Jadi, Perusahaan adalah organisasi bisnis yang bertujuan untuk mengelola bisnis. ${ }^{18}$

Koperasi juga merupakan badan hukum, ${ }^{19}$ sebagaimana diatur dalam UU Nomor 17 Tahun 2012 tentang Perkoperasian yang menggantikan ketentuan lama

\footnotetext{
${ }_{17}$ Niru Anita Sinaga, "Hal-Hal Pokok Pendirian Perseroan terbatas Di Indonesia", Jurnal Ilmiah Hukum Dirgantara-Fakultas hukum Universitas Dirgantara Marsekal Suryadarma, Vol. 8 No. 2 Maret 2018, hlm. 23.

18 Ridwan Khairandy, "Karakter Hukum Perusahaan Perseroan dan Status Hukum Kekayaan yang Dimilikinya”, Jurnal Hukum Ius Quia Iustum No. 1. Vol. 20 Januari 2013, hlm. 84-85.

19 Menurut Pasal 1 angka 1 UU Nomor 17 Tahun 2012: Koperasi adalah badan hukum yang didirikan oleh orang perseorangan atau badan hukum Koperasi, dengan pemisahan kekayaan para anggotanya sebagai
} 
yaitu UU Nomor 25 Tahun 1992. Keberadaan koperasi merupakan amanat UndangUndang Dasar 1945. Pasal 33 ayat (1) UUD 1945 menegaskan bahwa perekonomian disusun sebagai usaha bersama berdasar atas asas kekeluargaan. Ketentuan tersebut sesuai dengan prinsip Koperasi, karena misi dari koperasi adalah berperan nyata dalam menyusun perekonomian yang berdasar atas asas kekeluargaan dan demokrasi ekonomi yang mengutamakan kemakmuran masyarakat bukan kemakmuran orang-seorang. Pasal 4 UU Perkoperasian menyatakan koperasi bertujuan meningkatkan kesejahteraan anggota pada khususnya dan masyarakat pada umumnya, sekaligus sebagai bagian yang tidak terpisahkan dari tatanan perekonomian nasional yang demokratis dan berkeadilan. Sebagai wadah kumpulan usaha sejenis yang memiliki kepentingan yang sama baik untuk meningkatkan efisiensi dan produktivitas yang penuh dengan nilai-nilai universal merupakan kekuatan dasar membangun modal sosial. ${ }^{20}$

Nilai yang mendasari kegiatan Koperasi yaitu: kekeluargaan, menolong diri sendiri, dan bertanggung jawab. Maknanya koperasi dalam melaksanakan usahanya mengutamakan kemakmuran anggota pada khususnya dan masyarakat pada umumnya, bukan kemakmuran orang-perseorangan. Semua anggota koperasi berkemauan dan sepakat secara bersama-sama menggunakan jasa koperasi untuk memenuhi kebutuhannya dan mempromosikan koperasi sehingga menjadi kuat, sehat, mandiri, dan besar. Segala kegiatan usaha koperasi harus dilaksanakan dengan prinsip profesionalitas dalam kemampuan dan tanggung jawab, efisiensi dan efektifitas yang dapat menjamin terwujudnya nilai tambah yang optimal bagi koperasi. ${ }^{21}$

Nilai atau prinsip tersebut merupakan kekuatan koperasi yang membedakan nya dengan badan usaha lain dan mampu bertahan menghadapi berbagai tantangan di era global. Prinsip-prinsip koperasi berdasarkan ICA Identity Cooperative Statement (IICS) adalah:22 Voluntary and open membership,

\footnotetext{
modal untuk menjalankan usaha, yang memenuhi aspirasi dan kebutuhan bersama di bidang ekonomi, sosial, dan budaya sesuai dengan nilai dan prinsip Koperasi.

${ }^{20}$ Muslimin Nasution, Koperasi Menjawab Kondisi Ekonomi Nasional, Pusat Informasi Perkoperasian, Jakarta, 2008, hlm. 6.

${ }^{21}$ Pasal 5 ayat (1) UU Nomor 17 Tahun 2012 dan Penjelasannya.

22 Andjar Pachta W., Myra Rosana Bachtiar, dan Nadia Maulisa Benemy, Hukum Koperasi Indonesia, Kencana Prenada Media Group, Jakarta, 2012, hlm. 22-25
} 
Democratic member control, Member economic participation, Autonomy and independence, Education, training, and information, Cooperation among cooperatives, and Concern for community. Sedangkan nilai yang diyakini koperasi ada 4 yaitu: 1) kejujuran; 2) keterbukaan, 3) bertanggung jawab, dan 4) kepedulian terhadap orang lain. Menurut artikulasi International Labour Organisation (ILO), prinsip dan nilai koperasi adalah "... include but not limited to self-help, self responsibility, democracy, equality, equity, and solidarity. ${ }^{23}$

Adapun legalitas Usaha Bersama (Mutual) sebagai badan hukum penyelenggara usaha perasuransian tertuang dalam Pasal 7 UU Nomor 2 Tahun 1992 tentang Usaha Perasuransian, yang kemudian ditegaskan ulang dalam UU yang menggantikannya yaitu UU Nomor 40 Tahun 2014 tentang Perasuransian. Penjelasan Pasal 7 ayat (3) UU Usaha Perasuransian menyatakan mengingat Undang-undang mengenai bentuk hukum Usaha Bersama (Mutual) belum ada, maka untuk sementara ketentuan tentang usaha perasuransian yang berbentuk Usaha Bersama (Mutual) akan diatur dengan Peraturan Pemerintah. Artinya UU tersebut sebenarnya memberikan 'amanat' untuk terbitnya UU tentang Usaha Bersama (Mutual). Namun demikian 22 tahun berselang tidak kunjung juga realisasi amanat tersebut, baik berupa terbitnya PP apalagi UU. UU yang kemudian terbit, sebagaimana uraian sebelumnya, adalah UU Nomor 40 Tahun 2014 yang bukannya mengatur mengenai badan hukum Usaha Bersama, melainkan mengatur tentang Asuransi menggantikan UU Nomor 2 Tahun 1992. UU yang baru ini, bahkan telah memarginalkan bentuk badan hukum Usaha Bersama, dikarenakan hanya mengakui eksistensi badan hukum Usaha Bersama yang telah ada pada saat UU tersebut diundangkan.

Berdasarkan hal tersebut di atas, maka hanya ada satu badan hukum mutual di Indonesia berdasarkan UU Nomor 40 Tahun 2014, yaitu Asuransi Jiwa Bersama (AJB) Bumiputera 1912. AJB Bumiputera 1912 sendiri merupakan usaha asuransi jiwa nasional yang pertama dan tertua di Indonesia, yang lahir di masa pergerakan nasional yang bertujuan meningkatkan derajat ekonomi bangsa. Perkumpulan atau usaha asuransi ini didirikan oleh beberapa guru Hindia

23 Dian Cahyaningrum, "Bentuk badan Hukum Koperasi Untuk Menjalankan KegiatanUsaha Perbankan”, Jurnal Negara Hukum, Vo. 8, No. 1, Juni 2017, hlm. 8. 
Belanda terbentuk pada 12 Februari 1912, di Magelang, Jawa Tengah, dengan nama Onderlinge Levensverzekering Maatschapij Persatoean Goeroe-goeroe Hindia Belanda disingkat dengan O.L Mij. PGHB atau lebih dikenal dengan bahasa Inggrisnya Mutual Life Insurance (Asuransi Jiwa Bersama), dengan Akta Notaris De Hondt yang berkedudukan di Yogyakarta dan sah menurut hukum sejak beridirinya sebagai bentuk usaha untuk melakukan perbuatan hukum perdata berdasarkan Pasal 10 Keputusan Kerajaan Belanda 28 Maret 1870 (dua puluh delapanmaret seribu delapanratus tujuhpuluh) Nomor 2 Stb 64 sesuai Surat Sekretaris Gubernur Jenderal Hindia Belanda tanggal 06-04-1915 (enam April seribu sembilan ratus lima belas). ${ }^{24}$ Bentuk badan usaha yang seperti ini, maka pemilik badan usahanya adalah para pemegang polis.

Dalam perkembangannya beberapa kali mengalami perubahan dan namanya berubah menjadi Maskapai Asuransi Djiwa Boemi Poetera 1912 yang Anggaran Dasarnya disahkan oleh Badan Pengawas Pertanggoengan Djiwa bertanggal 29-06-1956 (dua puluh sembilan Juni seribu sembilan ratus lima puluh enam) Nomor 94/451.7. Selanjutnya mengalami perubahan menjadi Anggaran Dasar 1967 yang disahkan oleh Direktorat Perasuransian Departemen Keuangan bertanggal 09-12-1966 (sembilan Desember seribu sembilanratus enampuluh enam) Nomor D.A.D/05/66, didaftarkan di Kantor Pengadilan Negeri Jakarta Nomor 1782, dimuat dalam Berita Negara Tahun 1967 Nomor 16 dan Tambahan Berita Negara bertanggal 12-12-1967 (dua belas Desember seribu sembilan ratus enam puluh tujuh) Nomor 99.25

Pada dasarnya Usaha Bersama (Mutual) bukanlah merupakan persekutuan modal, seperti halnya PT, melainkan persekutuan orang yang pondasinya kebersamaan para anggotanya dengan tujuan mensejahterakan seluruh anggotanya. Pendirian Mutual bersifat demi kebersamaan, tidak ada niat atau motif untuk dijual lagi (motif keuntungan), jadi manajemen fokus pada pemegang polis, yang juga sekaligus sebagai pemegang saham, tidak mendua seperti PT. Secara filosofis, konsep Usaha Bersama (Mutual) sangat indah. Anggota sekaligus pemilik saling tolong menolong dalam kesusahan dan

\footnotetext{
24 Putusan Mahkamah Konstitusi RI Nomor 32/PUU-XI/2013, hlm. 7-8.

${ }^{25}$ Ibid.
} 
ketidakberdayaan, jika mendapatkan keuntungan dan kerugian dipikul bersama dan sudah terbukti bahwa mutual sudah hidup ratusan tahun.

PT, Koperasi dan Mutual, sebagai badan hukum penyelenggara usaha perasuransian, masing-masing memiliki karakteristik sendiri, berbeda satu dengan lainnya. Secara singkat perbedaan dapat dijelaskan dalam tabel berikut:

Perbedaan PT, Koperasi dan Mutual sebagai Badan Hukum Perasuransian

\begin{tabular}{llll}
\hline \multicolumn{1}{c}{ Perbedaan } & \multicolumn{1}{c}{ PT } & \multicolumn{1}{c}{ Koperasi } & \multicolumn{1}{c}{ Mutual } \\
\hline Dasar Hukum (UU) & - UU 40 Tahun 2007 & - UU 17 Tahun 2012 & UU 40 Tahun \\
& - UU 40 Tahun 2014 & - UU 40 Tahun 2014 & 2014 \\
Jenis Persekutuan & Persekutuan Modal & Persekutuan Orang & $\begin{array}{l}\text { Persekutuan } \\
\text { Orang }\end{array}$ \\
& & & Kebersamaan \\
Asas/Sifat & Individual/Kapitalistik & Kebersamaan & Kesejahteraan \\
Tujuan/orientasi & Keuntungan Pemilik & Kesejahteraan & anggota \\
& & Anggota & BPA, Direksi, \\
Organ & RUPS, Direksi, & Rapat Anggota, & Komisaris \\
& Komisaris & Pengawas, Pengurus & Komata \\
Pembagian & Deviden Pemegang & SHU dibagi ke & Hak Anggota \\
Hasil/laba & Saham & Anggota & (bonus) \\
Kedaulatan & Pemegang Saham & Anggota & Anggota \\
\hline
\end{tabular}

Secara hukum, konsekuensi dari masing-masing badan hukum penyelenggara perasuransian adalah bergantung pada karakteristik yang melekat pada badan hukum masing-masing. Usaha perasuransian yang berbentuk PT, berlaku ketentuan sebagaimana di atur dalam UU tentang PT. Perseroan Terbatas merupakan perusahaan perseroan yang dimiliki oleh beberapa orang dan/atau badan hukum yang memiliki saham di dalamnya. Dalam kegiatan operasionalnya, perusahaan mengandalkan pada besarnya permodalan perusahaan tersebut. Tujuan utamanya adalah untuk memperoleh keuntungan (terutama) bagi pemegang sahamnya. Keuntungan atau laba yang diperoleh menjadi hak pemegang saham dalam bentuk deviden, begitupun sebaliknya bila mengalami rugi, maka menjadi tanggung jawab pemegang saham.

Usaha Bersama (Mutual) mempunyai ciri atau karakteristik yang berbeda dengan Perusahaan Perseroan. Meskipun belum atau tidak ada Undang-undang yang mengatur secara khusus Usaha Bersama (Mutual), dan hanya disebut dalam UU Perasuransian, namun karakteristik atau konsekuensi pilihan badan hukum 
ini sangat jelas dan berkesesuaian bahkan sebagai pengejawantahan dari amanat Pasal 33 ayat (1) UUD 1945. Kepemilikan Mutual berada pada seluruh pemegang polisnya. Dalam kegiatan operasionalnya tidak mengandalkan modal (tidak ada modal), melainkan sebagian premi yang dibayar oleh pemegang polis (komponen biaya pada premi). Selanjutnya bila memperoleh laba, maka laba tersebut menjadi hak pemegang polis dalam bentuk bonus, sebaliknya bila mengalami rugi, maka manfaat yang akan diterima pemegang polis berkurang secara proporsional terhadap kerugian.

Koperasi memiliki karakteristik yang hampir sama dengan Usaha Bersama (Mutual). Kelebihannya badan hukum Koperasi telah mendapatkan pengaturan pengaturan dalam bentuk Undang-undang (UU Nomor 25 Tahun 1992 dan kemudian diganti dengan UU Nomor 17 Tahun 2012). Koperasi merupakan badan hukum yang didirikan, dimiliki dan dioperasionalkan oleh orangperorangan. Dalam perkembangannya, sebagaimana di atur dalam UU Perkoperasian, pendirian koperasi sekunder bisa pula dilakukan beberapa badan hukum koperasi. Koperasi melandaskan kegiatannya berdasarkan prinsip gerakan ekonomi rakyat yang berdasarkan asas kekeluargaan. Apabila memperoleh keuntungan/laba, maka laba tersebut menjadi hak anggota koperasi, sebaliknya bila mengalami rugi, maka manfaat yang akan diterima oleh anggota koperasi berkurang secara proporsional terhadap kerugian.

\section{Badan Hukum Ideal Penyelenggara Asuransi}

Pasal 1 angka 1 UU Nomor 40 Tahun 2014 menyatakan asuransi adalah perjanjian antara dua pihak, yaitu perusahaan asuransi dan pemegang polis, yang menjadi dasar bagi penerimaan premi oleh perusahaan asuransi sebagai imbalan untuk: (a) memberikan penggantian kepada tertanggung atau pemegang polis karena kerugian, kerusakan, biaya yang timbul, kehilangan keuntungan, atau tanggung jawab hukum kepada pihak ketiga yang mungkin diderita tertanggung atau pemegang polis karena terjadinya suatu peristiwa yang tidak pasti; atau (b) memberikan pembayaran yang didasarkan pada meninggalnya tertanggung atau pembayaran yang didasarkan pada hidupnya tertanggung dengan manfaat yang besarnya telah ditetapkan dan/atau didasarkan pada hasil pengelolaan dana. 
Dalam UU Perasuransian juga merumuskan asuransi syariah sebagai kumpulan perjanjian, yang terdiri atas perjanjian antara perusahaan asuransi syariah dan pemegang polis dan perjanjian di antara para pemegang polis, dalam rangka pengelolaan kontribusi berdasarkan prinsip syariah guna saling menolong dan melindungi dengan cara: (a) memberikan penggantian kepada peserta atau pemegang polis karena kerugian, kerusakan, biaya yang timbul, kehilangan keuntungan, atau tanggung jawab hukum kepada pihak ketiga yang mungkin diderita peserta atau pemegang polis karena terjadinya suatu peristiwa yang tidak pasti; atau (b) memberikan pembayaran yang didasarkan pada meninggalnya peserta atau pembayaran yang didasarkan pa.da hidupnya peserta dengan manfaat yang besarnya telah ditetapkan dan/atau didasarkan pada hasil pengelolaan dana. ${ }^{26}$

Pengelolaan asuransi diselenggarakan oleh suatu badan/perusahaan/ lembaga yang sengaja dirancang dan dibentuk sebagai lembaga pengambil alih dan penerima resiko. Pada dasarnya, penyelenggara menawarkan produk berupa jasa proteksi kepada masyarakat yang membutuhkan, dan selanjutnya diharapkan akan menjadi pelanggannya. Untuk mencapai tujuan tersebut, penyelenggara asuransi mengajak setiap pihak untuk bergabung ataupun bekerjasama untuk menghadapi kemungkinan-kemungkinan kerugian yang mungkin terjadi yang biasanya tidak disadari dan tidak siap dihadapi.

Asuransi membawa misi ekonomi sekaligus sosial dengan adanya premi yang dibayarkan kepada penyelenggara usaha asuransi dengan jaminan adanya pengalihan (transfer) resiko dari tertanggung kepada penanggung. Asuransi sebagai mekanisme pemindahan resiko dimana seseorang atau badan hukum memindahkan sebagian ketidakpastian sebagai imbalan pembayaran premi. Definisi resiko disini adalah ketidakpastian terjadi atau tidaknya suatu kerugian.

Minat usaha di bidang asuransi baik konvensional maupun syariah terus mengalami kenaikan. Literasi masyarakat mengenai asuransi yang meningkat telah menarik sejumlah pelaku usaha untuk mendirikan usaha perasuransian. Jumlah perusahaan asuransi (baik Syariah maupun konvensional) secara

${ }^{26}$ Pasal 1 angka 1 UU Nomor 40 Tahun 2014 tentang Perasuransian 
keseluruhan hingga Maret tahun 2020 adalah sebanyak 152 perusahaan, dengan rincian 61 perusahaan asuransi jiwa, 79 asuransi umum, 7 reasuransi, 3 asuransi wajib, dan 2 asuransi sosial (BPJS), sebagaimana tabel berikut:

\begin{tabular}{lccc}
\hline \multirow{2}{*}{ Jenis Asuransi } & \multicolumn{2}{c}{ Pelaku Usaha } & \multirow{2}{*}{ Total } \\
\cline { 2 - 3 } & Konvensional & Syariah* & \\
\hline Asuransi Jiwa & 52 & 7 & 59 \\
Asuransi Umum & 72 & 5 & 77 \\
Reasuransi & 6 & 1 & 7 \\
Asuransi Wajib & 3 & 0 & 3 \\
Asuransi Sosial (BPJS) & 2 & - & 2 \\
\hline \multicolumn{1}{c}{ Jumlah } & $\mathbf{1 3 5}$ & $\mathbf{1 3}$ & $\mathbf{1 4 8}$ \\
\hline
\end{tabular}

*Data Full Fledge Syariah

Data: Otoritas Jasa Keuangan, Statistik IKNB Periode Februari 2021

Untuk asetnya tercatat di Februari 2021 sebesar 1.494 .969 miliar atau 1.494,97 triliun dengan rincian sebagai berikut:

\begin{tabular}{lrrr}
\hline \multirow{2}{*}{ Jenis Asuransi } & \multicolumn{2}{c}{ Pelaku Usaha } & \multirow{2}{*}{ Total } \\
\cline { 2 - 3 } & Konvensional & \multicolumn{1}{c}{ Syariah } & \multicolumn{1}{c}{} \\
\hline Asuransi Jiwa & $554.384,21$ & $36.479,55$ & $590.863,76$ \\
Asuransi Umum & $177.468,52$ & $6.137,45$ & $183.605,97$ \\
Reasuransi & $29.603,22$ & $2.097,20$ & $31.700,42$ \\
Asuransi Wajib & $136.278,89$ & - & $136.278,89$ \\
Asuransi Sosial (BPJS) & $552.520,37$ & - & $552.520,37$ \\
\hline \multicolumn{1}{c}{ Jumlah } & $\mathbf{1 . 4 5 0 . 2 5 5 , 2 0}$ & $\mathbf{4 4 . 7 1 4 , 2 0}$ & $\mathbf{1 . 4 9 4 . 9 6 9 , 4 0}$ \\
\hline
\end{tabular}

Data: Otoritas Jasa Keuangan, Statistik IKNB Periode Februari 2021

Dari seluruh pelaku usaha perasuransian semuanya berbentuk badan hukum Perseroan Terbatas/PT (Persero) kecuali AJB Bumi Putera yang badan hukumnya berbentuk Usaha Bersama (Mutual), dan tidak satu pun yang berbentuk Koperasi.

Perseroan Terbatas adalah badan hukum yang merupakan persekutuan modal, didirikan berdasarkan perjanjian, melakukan kegiatan usaha dengan modal dasar yang seluruhnya terbagi dalam saham dan memenuhi persyaratan yang ditetapkan dalam UU ini serta peraturan pelaksanaannya. Meskipun di dalam UU PT tidak mengatur mengenai tujuannya secara jelas, namun dengan adanya pengaturan mengenai modal, baik modal dasar, ditempatkan maupun disetor, tata cara penggunaan laba serta deviden, maka dapat dipastikan orientasinya adalah untuk mencari keuntungan. 
Penegasan bahwa perusahaan bertujuan untuk memperoleh keuntungan diatur dalam UU Nomor 3 Tahun 1982. Pasal 1 huruf b, menyatakan Perusahaan adalah setiap bentuk usaha yang menjalankan setiap jenis usaha yang bersifat tetap dan terus menerus dan yang didirikan, bekerja serta berkedudukan dalam wilayah Negara Republik Indonesia, untuk tujuan memperoleh keuntungan dan atau laba. Meskipun dalam Pasal 6 berikut penjelasan UU tersebut juga mengatur adanya bentuk perusahaan yang dinyatakan tidak bertujuan untuk mencari keuntungan atau laba, seperti perusahaan negara berbentuk perusahaan jawatan (Perjan). 27

Koperasi juga merupakan badan hukum yang didirikan oleh orang perseorangan atau badan hukum Koperasi, dengan pemisahan kekayaan para anggotanya sebagai modal untuk menjalankan usaha, yang memenuhi aspirasi dan kebutuhan bersama di bidang ekonomi, sosial, dan budaya sesuai dengan nilai dan prinsip Koperasi. Pasal 2 UU Perkoperasian menyatakan bahwa koperasi berlandaskan Pancasila dan Undang-Undang Dasar Negara Republik Indonesia Tahun 1945. Pasal 33 ayat (1) UUD 1945 menegaskan bahwa perekonomian disusun sebagai usaha bersama berdasar atas asas kekeluargaan. Ketentuan tersebut sesuai dengan prinsip koperasi, karena itu koperasi mendapat misi untuk berperan nyata dalam menyusun perekonomian yang berdasar atas asas kekeluargaan dan demokrasi ekonomi yang mengutamakan kemakmuran masyarakat bukan kemakmuran orang-seorang.

Meskipun koperasi sudah sangat dikenal, bahkan disebut sebagai soko guru ekonomi Indonesia, namun hingga sekarang ini tidak ada satupun perusahaan ber badan hukum koperasi sebagai penyelenggara perasuransian. Koperasi berstatus sebagai badan hukum yang modalnya berasal dari simpanan para anggota. Koperasi juga bertujuan untuk mencari keuntungan, namun sebagai tujuan utamanya adalah untuk mensejahterakan anggotanya. Persaingannya dengan PT sebagai penyelenggara perasuransian, mengakibatkan persyaratan dan kompetisi yang ketat serta tuntutan profesionalisme tinggi dalam bisnis asuransi, bisa jadi membuat kegamangan memilih opsi badan hukum koperasi.

${ }^{27}$ Dalam perkembangan nya beberapa Perjan dicabut, dan diganti/dialihkan menjadi Persero, Perum atau Badan Layanan Umum (BLU). 
Terlebih untuk memutuskan pilihan bisnis tersebut harus mendasarkan pada keputusan rapat anggota yang merupakan pemegang kekuasaan tertinggi dalam koperasi.

Koperasi memang memiliki keunikan, sebagai badan usaha sekaligus perkumpulan individu. Untuk itu koperasi harus dapat menjaga keseimbangan antara praktik-praktik bisnis komersial dan hubungan antar individu di dalamnya. Koperasi adalah organisasi demokratis yang dikontrol oleh anggotanya. Mereka memilih pengurus yang berasal dari anggota untuk menjadi perwakilan anggota dalam mengelola kegiatan koperasi. Tujuan utama koperasi adalah memenuhi kebutuhan anggota dan memastikan kepuasan anggota, bukan sekedar menghasilkan profit. 28

Perusahaan mutual juga memiliki keunggulan karena adanya penyatuan fungsi kepemilikan dan fungsi konsumen. Konsumen perusahaan mutual yaitu para nasabah pemegang polis asuransi juga berstatus sebagai pemilik perusahaan. Keunikan ini bisa berdampak positif mengurangi potensi konflik kepentingan antara konsumen dengan pemilik perusahaan yang umum terjadi di perusahaan berbentuk PT. Penyatuan fungsi kepemilikan dan konsumen menyebabkan perusahaan mutual dapat hidup lebih dari seratus tahun di berbagai negara. Sepanjang berdirinya AJBB tidak pernah mengalami penarikan polis secara masif (rush) meskipun negara dalam keadaan krisis, sejak zaman krisis pemotongan uang (sanering) 1966, krisis moneter 1998, hingga krisis keuangan global 2008. ${ }^{29}$

Setelah 5 tahun berselang sejak terbitnya UU Nomor 40 Tahun 2014, tepatnya pada 26 Desember 2019, terbit Peraturan Pemerintah (PP) Nomor 87 Tahun 2019 tentang Perusahaan Asuransi Berbentuk Usaha Bersama. PP ini dimaksudkan untuk melaksanakan ketentuan Pasal 6 ayat (3) UU Perasuransian. Sesungguhnya amanat Putusan MK Nomor 32/PUU-XI/2013 adalah memerintahkan pembentukan Badan Hukum Usaha Bersama (Mutual) dalam bentuk UU, namun Presiden dan DPR selaku pembentuk UU "tidak mentaati"

${ }^{28}$ Dian Cahyaningrum, Op. Cit., hlm. 8.

${ }^{29}$ Iswi Hariyani, "Kajian hukum Restrukturisasi Asuransi jiwa Bersama Bumiputera 1912 Sebagai Perusahaan Mutual”, Jurnal Hukum Ius Quia Iustum, Fakultas Hukum UII, Yogyakarta, Nomor 2 Volume 24, 24 April 2017, hlm. 328. 
perintah konstitusional tersebut. Dalam pertimbangan hukum Putusan MK Nomor 32/PUU-XVII/2020 (uji materiil terhadap UU Nomor 40 Tahun 2014), kembali Mahkamah memperingatkan agar Presiden dan DPR membentuk UU tentang Usaha Bersama (Mutual). Artinya ketentuan tentang usaha perasuransian yang berbentuk Usaha Bersama (Mutual) harus diatur lebih lanjut dengan UU tersendiri terpisah dari asuransi berbentuk perseroan dan asuransi berbentuk koperasi. Tindakan tidak membuat UU khusus tentang Usaha Bersama (Mutual) dengan dalih/alasan keterbatasan permodalan, oleh Mahkamah dipandang bukan merupakan alasan konstitusional melainkan alasan teknis-pragmatis belaka. Mengingat usaha asuransi berbentuk usaha bersama di negara lain berkembang dan maju menjadi perusahaan asuransi yang besar seperti di Jepang, Perancis, Denmark, Norwegia, Swedia, Belgia, Finlandia, Polandia, Slovenia, Spanyol, Amerika Serikat, serta di Afrika Selatan. Bahkan perusahaan asuransi yang mengadopsi bentuk usaha bersama justru berkembang dengan sukses dan menjadi perusahaan multi-nasional yang memiliki cabang di banyak negara, seperti The Folksam Group di negara Swedia, Liberty Mutual Insurance di Amerika Serikat, The MACIF Group di negara Perancis, dan Old Mutual Life Assurance Company di negara Afrika Selatan. ${ }^{30}$ Pemerintah menunjukkan keberpihakannya pada bentuk badan hukum PT sebagai penyelenggara perasuransian, dan 'setengah hati' terhadap keberadaan Usaha Bersama (Mutual).

Tidak berkembangnya bentuk badan hukum hukum mutual maupun koperasi disebabkan adanya beberapa permasalahan hukum yang dihadapi dalam menjalankan kegiatan di bidang asuransi. Di satu sisi harus tunduk pada peraturan perundang-undangan di bidang perasuransian, di sisi yang lain, juga harus tunduk pada peraturan perundang-undangan berkaitan dengan bentuk badan usahanya. Selain itu peraturan perundang-undangan di bidang perasuransian lebih banyak mengatur dan memberikan pedoman untuk asuransi yang berbentuk PT. Koperasi maupun mutual harus mengacu atau menganologikannya dengan PT, padahal karakteristik dan aturan kedua badan hukum tersebut memiliki perbedaan yang signifikan.

${ }^{30}$ Putusan Mahkamah Konstitusi Nomor 32/PUU-XVII/2020, hlm. 124. 
PT merupakan organisasi berwatak kapitalis yang bertujuan untuk mencari keuntungan. Modalnya terbagi dalam saham yang dijual kepada siapa pun yang berminat tanpa memperhatikan sifat-sifat pembeli saham yang bersangkutan. Umumnya saham tersebut diperjualbelikan sehingga PT mudah untuk berpindah tangan. PT mempunyai ciri-ciri: didirikan dengan akta notaris dan disahkan oleh Kementerian Hukum dan Hak Asasi Manusia; merupakan persekutuan modal; tidak langsung mengerjakan kepentingan anggota; anggota bersifat menunggu; maju-mundurnya usaha bergantung pada kecakapan direksinya; hak suara dalam rapat anggota seimbang dengan besar kecilnya saham yang dipegang oleh para anggota masing-masing; besar kecilnya keuntungan berdasarkan kepada jumlah saham yang dimiliki dan besarnya keuntungan yang diterima dibatasi; dan PT umumnya acuh terhadap kesejahteraan masyarakat. ${ }^{31}$

Adapun untuk Koperasi Primer didirikan oleh paling sedikit 20 orang perseorangan dengan memisahkan sebagian kekayaan pendiri atau anggota sebagai modal awal Koperasi, sedangkan Koperasi Sekunder didirikan oleh paling sedikit 3 Koperasi Primer. Akta pendirian koperasi dibuat oleh Notaris dan di daftarkan dan disahkan pada kementrian di bidang koperasi (Kementrian Kopersi dan UKM). Koperasi merupakan perkumpulan orang bukan modal, Anggota berpartisipasi aktif dalam menentukan kebijakan dan membuat keputusan serta usaha dititikberatkan pada kebutuhan anggotanya; majumundurnya usaha koperasi tergantung pada keaktifan para anggotanya; tiap-tiap anggota mempunyai satu suara; koperasi tidak mengenal keuntungan (deviden) melainkan sisa hasil usaha (SHU).

Tidak jauh berbeda dengan koperasi, Mutual juga bukan merupakan persekutuan modal, seperti halnya PT, melainkan persekutuan orang yang pondasinya kebersamaan para anggotanya dengan tujuan mensejahterakan seluruh anggotanya. Pendirian Mutual bersifat demi kebersamaan. Mutual ini mirip dengan Persekutuan Perdata, yang merupakan persetujuan antara dua orang atau lebih yang berjanji untuk memasukkan sesuatu ke dalam persekutuan itu dengan maksud supaya keuntungan yang diperoleh dari persekutuan itu

\footnotetext{
31 Pandji Anoraga dan Ninik Widiyati, Dinamika Koperasi, Rineka Cipta, 2007, hlm. 65-66. Lihat juga Dian Cahyaningrum, Op. Cit., hlm. 17.
} 
dibagi di antara mereka (Pasal 1618 KUHPerdata). Perbedaannya, perusahaan mutual tergolong badan hukum dan memiliki banyak anggota, sedangkan persekutuan perdata bukan badan hukum dan hanya memiliki sedikit anggota.

Memang dengan terbitnya Peraturan OJK No. 1/POJK.05/2018 tentang Perusahaan Asuransi Berbentuk Badan Hukum Usaha Bersama dinilai memberikan ruang relaksasi bagi asuransi mutual. Lebih dari satu dekade terakhir, satu-satunya, badan hukum mutual (AJBB) diterpa urusan regulasi dengan penerapan peraturan yang berbasis perseroan terbatas yang ketat, padahal mutual bukanlah persekutuan modal. Aturan tentang kesehatan keuangan asuransi sebelumnya yaitu Keputusan Menteri Keuangan No. 504/KMK.06/2004 tentang Kesehatan Keuangan Bagi Perusahaan Asuransi Yang Berbentuk Badan Hukum Bukan Perseroan Terbatas justru memberi ketentuan yang lebih ketat. Dalam KMK No.504/2004, perusahaan asuransi diwajibkan untuk memenuhi tingkat likuiditas secara bertahap, yakni dari paling rendah $120 \%$ pada akhir kuartal III/2004 hingga minimal 200\% sejak akhir 2006. Kelonggaran juga diberikan terkait pembentukan dana jaminan. Aturan terdahulu mewajibkan asuransi setiap tahun menyesuaikan jumlah deposito jaminan sekurang-kurangnya Rp. 400.000.000,00 ditambah dengan 3\% dari cadangan premi termasuk cadangan premi yang berlum merupakan pendapatan. Dalam POJK diatur dana jaminan dibentuk paling rendah $2 \%$ dari cadangan premi atas produk asuransi yang dikaitkan dengan investasi (PAYDI) ${ }^{32}$, ditambah 3\% dari cadangan premi selain PAYDI dan cadangan premi yang belum merupakan pendapatan.

Ketentuan lainnya yang berdampak signifikan adalah tingkat solvabilitas ${ }^{33}$ yang menyebutkan bahwa target tingkat solvabilitas internal ditetapkan paling rendah $120 \%$ dari dana minimum berbasis risiko (DMBR) ${ }^{34}$ dengan memperhitungkan profil risiko setiap perusahaan serta mempertimbangkan

32 PAYDI adalah Produk Asuransi Yang Dikaitkan Dengan Investasi. Lihat Pasal 1 angka 3 POJK Nomor 1/POJK.05/2018 tentang Kesehatan Keuangan Bagi Perusahaan Asuransi Berbentuk Badan Hukum Usaha Bersama.

33 Tingkat Solvabilitas adalah selisih antara jumlah aset yang diperkenankan dikurangi dengan jumlah liabilitas. Lihat Pasal 1 angka 7 POJK Nomor 1/POJK.05/2018.

34 DMBR adalah jumlah dana yang dibutuhkan untuk mengantisipasi risiko kerugian yang mungkin timbul sebagai akibat dari deviasi dalam pengelolaan aset dan Liabilitas. 
hasil simulasi skenario perubahan (stress test). Sekilas ketetapan itu tidak jauh berbeda dari tingkat solvabilitas yang menjadi ukuran kesehatan di perusahaan asuransi berbentuk badan hukum perseroan terbatas dan koperasi sebagaimana di atur dalam POJK No. 71/POJK.05/2016. ${ }^{35}$ Apabila pada asuransi usaha bersama dibandingkan dengan DMBR, maka pada asuransi berbentuk PT dan koperasi diperhitungkan dari modal minimum berbasis risiko $(\mathrm{MMBR})^{36}$. Solvabilitas tidak lagi mengacu pada jumlah ekuitas. ${ }^{37}$

Berbagai regulasi berkaitan dengan perasuransian menunjukkan bahwa pemerintah berpandangan bentuk badan hukum yang 'ideal' adalah PT. PT memiliki akses terkait dengan tuntutan permodalan yang kuat dalam pengembangan perusahaan asuransi melalui skema investasi dari investor yang kuat atau melalui pasar modal. Kekurangan permodalan dapat menurunkan layanan dan berdampak buruk bagi keberlangsungan perusahaan asuransi. Regulasi yang telah ada memberikan kesempatan bagi PT untuk meningkatkan permodalan melalui para pemegang saham/investor (termasuk foreign investors) atau melalui pasar modal dengan menerbitkan saham. Terkait dengan akses permodalan di atas, tidak dimiliki oleh Mutual maupun Koperasi.

\section{Penutup}

Berdasarkan penyajian analisis data di atas, Pembentuk UU menempatkan PT sebagai badan hukum ideal dalam penyelenggaraan perasuransian. Dari segi bisnis, PT memiliki keunggulan berupa kelangsungan perusahaan lebih terjamin karena tidak tergantung pada pemilik tertentu. Pemilik dapat berganti dengan memindahkan atau menjual sahamnya kepada pihak lain. Permodalan perusahaan dapat diperbesar karena adanya tambahan modal dengan mengeluarkan saham baru. Mitigasi risiko kerugian juga menjadi pertimbangan utama terkait dengan kesehatan keuangan perusahaan. Untuk mengatasi

35 POJK Nomor 71/POJK.05/2016 tentang Kesehatan Keuangan Perusahaan Asuransi dan Perusahaan Reasuransi

36 MMBR adalah jumlah dana yang dibutuhkan untuk mengantisipasi risiko kerugian yang mungkin timbul sebagai akibat dari deviasi dalam pengelolaan aset dan Liabilitas. Lihat Pasal 1 angka 11 POJK Nomor 71/POJK.05/2016.

${ }^{37}$ https://www.indopremier.com/ipotnews/newsDetail.php?jdl=Regulasi Mutual Insurance OJK Dinil ai Beri Relaksasi\&news id=328654\&group news=RESEARCHNEWS\&news date=\&taging subtype=REGU LATIONS\&name $=\&$ search $=\mathrm{y}$ general\&q $=$ peraturan $\% 20 \mathrm{OJK}, \% 20 \&$ halaman $=1$ 
persoalan tersebut, pada PT bisa dilakukan dengan menambah modal, tanpa dengan menimbulkan kewajiban baru bagi perusahaan. Penambahan modal pada PT sangat mungkin dilakukan baik oleh pemegang saham lama maupun oleh pemegang saham baru. PT dapat pula melakukan penggabungan (merger), peleburan (konsolidasi), atau pengambilalihan (akuisisi) dengan PT lain. Sedangkan pada perusahaan asuransi yang berbentuk mutual maupun koperasi, penambahan modal sulit dilakukan. Cara lain yang mungkin dilakukan untuk memperbaiki kondisi kesehatan perusahaan yang berbentuk usaha bersama adalah dengan memotong manfaat (benefit) yang menjadi hak pemegang polis, tetapi dalam praktik hal ini sulit dilaksanakan. Meskipun demikian, asuransi merupakan merupakan "bisnis kepercayaan". Koperasi dan (khususnya) Mutual memiliki keunggulan dalam penyatuan fungsi kepemilikan dan fungsi konsumen. Tujuan keduanya adalah lebih kepada kebersamaan serta memastikan kepuasan anggota dan bukan sekedar menghasilkan profit. Keunikan ini bisa berdampak positif mengurangi potensi konflik kepentingan antara konsumen dengan pemilik perusahaan yang umum terjadi pada PT. Fakta menunjukkan sepanjang berdirinya asuransi mutual AJBB (lebih dari satu abad) tidak pernah mengalami penarikan polis secara masif ( $r u s h$ ) meskipun negara mengalami krisis perekonomian baik nasional maupun global.

Koperasi maupun Usaha Bersama (Mutual) harusnya diberikan peluang yang lebih proporsional sebagai badan hukum yang dapat menjalankan usaha perasuransian dengan baik. Amanat Pasal 33 ayat (1) UUD 1945 yang menegaskan bahwa perekonomian disusun sebagai usaha bersama berdasar atas asas kekeluargaan, sudah semestinya gayung bersambut dengan kebijakan pengaturan perasuransian. Filosofi asuransi sesungguhnya sangat sesuai dengan jati diri badan hukum Mutual atau Koperasi. Jika pun ada 'kelemahan' terkait dengan problem permodalan maupun mitigasi risiko, maka jalan keluarnya bukan semakin 'mempersulit' atau 'memperberat' persyaratan yang harus dipenuhi oleh Koperasi maupun Mutual, melainkan memberikan jalan keluar baik dalam bentuk pengaturan dan pengawasan/supervisi oleh pemerintah. Pemerintah tengah diuji untuk melaksanakan amanat konstitusi (UUD 1945). 


\section{Daftar Pustaka}

\section{Buku}

Anoraga, Pandji, dan Ninik Widiyati, Dinamika Koperasi, Rineka Cipta, 2007.

Ganie, Junaedy, Hukum Asuransi Indonesia, Ctk. Pertama, Sinar Grafika, Jakarta, 2011.

Kertanegara, Sentanoe, Asuransi Jiwa dan Pensiun, Agung's, Jakarta, 1991.

Marzuki, Peter Mahmud, Penelitian Hukum, Edisi Revisi, Cetakan ke-12, Penerbit Kencana (Prenada Media Group), Jakarta, 2016.

Nasution, Muslimin, Koperasi Menjawab Kondisi Ekonomi Nasional, Pusat Informasi Perkoperasian, Jakarta, 2008.

Otoritas Jasa Keuangan, Statistik Industri Keuangan Non Bank (IKNB) Periode Februari 2021.

Pachta W., Andjar, Myra Rosana Bachtiar, dan Nadia Maulisa Benemy, Hukum Koperasi Indonesia, Kencana Prenada Media Group, Jakarta, 2012.

Projodikoro, Wirjono, Hukum Asuransi di Indonesia, Ctk. Kelima, Intermasa, Jakarta, 1991.

Rasjidi, Lili, dan Liza Sonia Rasjidi, Pengantar Metode Penelitian dan Penulisan Karya Ilmiah Hukum, FH UNPAD, Bandung, 2005.

Simanjuntak, Emmy Pangaribuan, Hukum Pertanggungan dan Perkembangannya, Badan Pembinaan Hukum Nasional, Departemen kehakiman, diterbitkan oleh seksi Hukum Dagang Fakultas Universitas Gadjah Mada, Edisi ke 1, Ctk. Pertama, 1980.

\section{Jurnal}

Dian Cahyaningrum, "Bentuk badan Hukum Koperasi Untuk Menjalankan Kegiatan Usaha Perbankan”, Jurnal Negara Hukum, Vo. 8, No. 1, Juni 2017.

Iswi Hariyani, “Kajian hukum Restrukturisasi Asuransi jiwa Bersama Bumiputera 1912 Sebagai Perusahaan Mutual", Jurnal Hukum Ius Quia Iustum, Fakultas Hukum UII, Yogyakarta, Nomor 2 Volume 24, 24 April 2017.

Niru Anita Sinaga, "Hal-Hal Pokok Pendirian Perseroan terbatas Di Indonesia”, Jurnal Ilmiah Hukum Dirgantara-Fakultas hukum Universitas Dirgantara Marsekal Suryadarma, Vol. 8 No. 2 Maret 2018.

Ridwan Khairandy, "Karakter Hukum Perusahaan Perseroan dan Status Hukum Kekayaan yang Dimilikinya", Jurnal Hukum Ius Quia Iustum No. 1. Vol. 20 Januari 2013.

\section{Dokumen Hukum}

Undang-Undang Nomor 40 Tahun 2007 tentang Perseroan terbatas

Undang-undang No. 40 Tahun 2014 tentang Perasuransian.

Undang-Undang No. 17 Tahun 2012 tentang Perkoperasian. 
Putusan Mahkamah Konstitusi Republik Indonesia Nomor 32/PUU-XI/2013.

Putusan Mahkamah Konstitusi Republik Indonesia Nomor 32/PUU-XVII/2020.

POJK Nomor 1/POJK.05/2018 tentang Kesehatan Keuangan Bagi Perusahaan Asuransi Berbentuk Badan Hukum Usaha Bersama.

POJK Nomor 71/POJK.05/2016 tentang Kesehatan Keuangan Perusahaan Asuransi dan Perusahaan Reasuransi.

POJK No. 2/POJK.05/2014 tentang Tata Kelola Perusahaan yang Baik Bagi Perusahaan Asuransi. 